\title{
The pair-bond imperative
}

\section{What's love got to do with it?}

\section{Jennifer Rohn}

After the third time Eve came home late from work, her mother Mary activated the trace. On the small hand-held, she watched her daughter linger at the door of the domed bee farm, standing too close to a fair-haired young man. There was laughter, there was head-ducking; there was a hand stretched out to touch a forearm: her hand, his forearm. Five minutes of conversation, lips moving in animation. Then, after a display of reluctant body language, they parted like a broken comb of sticky honey.

For the next three days, Mary tuned in for clocking-off time. The man always arrived first and waited until Eve emerged, shy eyes brightening, from her designated station. They had known each other long enough to fall into a pattern, Mary saw. Despite the unexpected loveliness Eve radiated, this girl on the cusp of womanhood, her mother was both embarrassed and alarmed by the rawness of the emotions in evidence. For Mary did not share Eve's delight when she looked at the man. No, all she could see was that his sandy-blond hair was only a shade lighter than her daughter's bronzy head; streaked with red in the sun, yes, but still technically blond. And straight, equally fine and straight. They could have been brother and sister.

The colony had stopped DNA typing and other molecular techniques long ago, when food and energy production had become the main priority and such technology had been deemed an unsustainable luxury. Instead, they relied on the ancient methods practised by early scientists such as Gregor Mendel: phenotypic differences as a measure of genetic distinction.

After the catastrophic epidemic that had taken Eve's grandparents along with nine-tenths of the colony's inhabitants, the gene pool was too small to permit anything other than the most ruthlessly disparate matches; even then it was still unclear whether the group had a long-term future. The need to survive made mating choice another luxury. Women had to have children by as many different, and dissimilar, fathers as possible, for as many years as they were able. To allow pair-bonding was impossible; attachments under such restrictions would be disastrous.

Eve knew the rules like everyone else, but, unlike her mother, when she looked at the man, who was called Paul, she stubbornly saw only differences. His hair was

like nothing else on the planetoid: it was the hue of honeycombs held up to the sun, glowing coppery-gold, or perhaps the soft shade of citron fuzz on the insects that
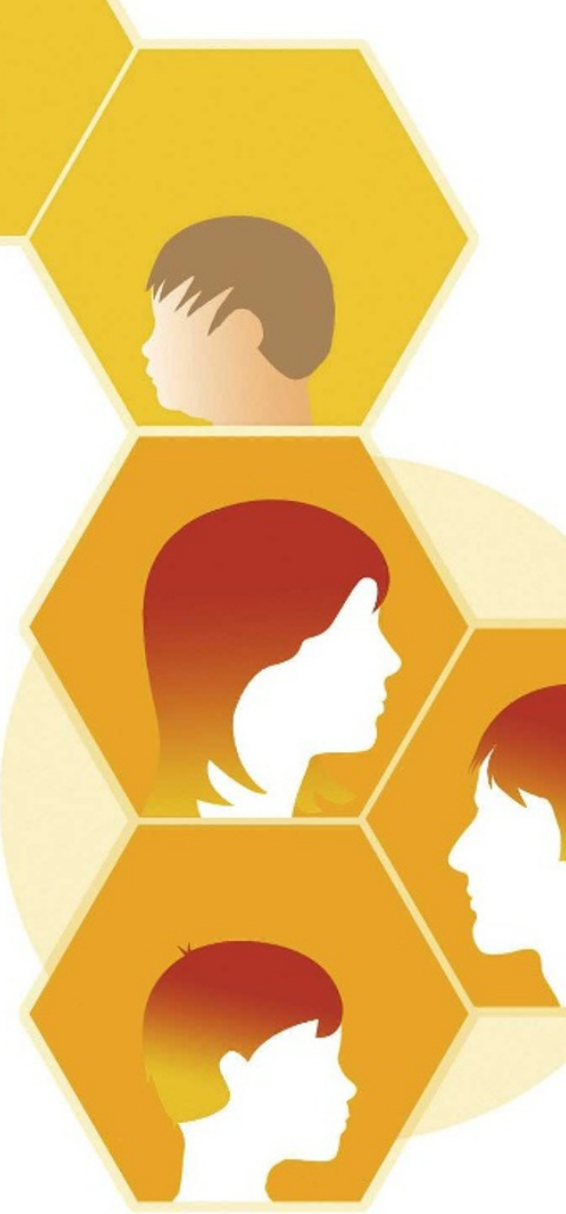

created them. His eyes weren't the same blue as hers or anyone else's; they were the blue of the midsummer double-solstice sky when the system's two suns remained half-set all night long, causing a perpetual twilight and a muted glow that blocked out the starlight. When she looked at him, she didn't think about her duty, or the survival of her people. She saw the knowing reciprocal glimmer of his face and felt a deep, implacable tug that had yet to be bred out of their species. She wanted, like a desire for food or water, something that was both part of him and part of her, though she had little conscious understanding of the underlying genetic imperative.

Meanwhile, Mary and her circle of halfsisters consulted with the local procreation officer. Yes, he agreed: although Eve was still a few months shy of her sixteenth birthday, the danger should be eliminated as soon as possible. Rules could be bent. After checking the database and finding the most dissimilar sperm donor possible - a dark-skinned, black-haired man whose psych appraisals suggested he was as docile as Eve was rebellious - the officer authorized the IVF personally.

Eve stood in the queue, close to tears, until the doctor was ready to see her. She was asked about her periods, given a rough uterine scan, and handed a vial of hormone tablets and strict instructions on how to begin taking them. And discharged, then, as perfunctorily as one of the sows whose insemination her half-brother oversaw a few domes down from the bee farm.

Paul had been transferred the day before, and they had not even had the chance to

say goodbye. But Eve called in a favour from another half-sister who worked in the labour-allocation unit. Late that night, after flushing the hormone tablets down the toilet, she climbed out of her bedroom window and met him in the cornfields. The air was warm and redolent of newly ploughed earth; the moons had set and pale stars were the only witness. Four weeks later when she arrived at her egg-harvesting appointment with news of a missed period, it was too late. New life was impossibly precious: no pregnancy could be terminated under the rules of the colony, no matter how genetically imprudent.

The baby boy had hair halfway between bronze and copper, like silk on an ear of corn. And he gazed at Eve with eyes somewhere between the blue of midnight and dawn. She was never allowed to see Paul again, but somehow, with the child, this was bearable. And although Eve bore many more children, Mary secretly thought that this particular grandchild was the most beautiful and distinctive of all.

Jennifer Rohn is a cell biologist at University College London and the editor of LabLit.com. Her first novel, Experimental Heart, comes out later this year. 